tendency of the university is towards technical and professional education, often for the purpose of examinations, enabling the scientific and natural history societies to provide, in addition to opportunities for research, the scientific background for those who wish to stand and stare. In this work his own Department could, and is anxious to, cooperate.

By a happy coincidence it was announced during the Congress that the award of O.B.E. had been conferred upon the president of the Richmond Scientific Society, Miss E. M. Wakefield, deputy keeper of the Herbarium and chief mycologist in the Royal Botanic Gardens, Kew, for her services to science.

\title{
STANDARDIZATION OF UNITS OF MEASUREMENT IN CIVIL AVIATION
}

\author{
By W. J. V. BRANCH \\ Air Navigation Commission, International Civil Aviation \\ Organisation, Montreal
}

\begin{abstract}
IST year it was announced that the Montreal 1 headquarters of the International Civil Aviation Organisation had obtained agreement on a plan to standardize the dimensional units used in air/ground communications in civil aviation and that this agreement has been implemented by a considerable number of countries (see Nature, July 2, 1949, p. 17). It is as yet impossible to say what final success this plan will have; but it is of interest to note some trends which are developing in the process of its implementation, and the following table shows the percentage of countries which have adopted units of the Organisation.
\end{abstract}

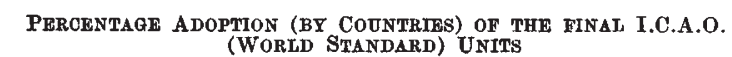

\begin{tabular}{ll} 
(1) Distances & Nautical miles \\
(2) Horizontal speed & Knots \\
(3) Wind direction and speed & Degrees and knots \\
(4) Altimeter setting & Millibars \\
(5) Temperature & Centigrade \\
(6) Time & 24 hours, the day beginning \\
\multicolumn{3}{l}{ at midnight G.M.T. } \\
(7) Altitudes, aerodrome dimen- \\
sions and short distances & Metres \\
(8) Vertical speed & Metres/second \\
(9) Cloud height & Metres \\
(10) Wisibility & Ketres or kilometres
\end{tabular}

These figures refer to countries of which the practices in this respect are officially. known; for example, the figure of 74 per cent for the distance units represents only thirty-two countries. It must also be emphasized that these figures do not necessarily reflect accurately the relative frequency with which the various units are used, since the percentages are related to countries and' do not take into account the relative contributions and importance to world aviation of each of the countries Thus, though the available records show that only' 12 per cent of the countries employ statute miles for the measurement of distance, the statute mile is nevertheless widely used for this purpose, since one of the countries using it, the United States, accounts for a very large percentage of the air miles flown.

It would seem that the first six units listed are quite certain to gain final world adoption. Probably the most interesting trend is the widespread agree- ment to use nautical miles and knots as the units for distances and horizontal speed-a clear indication of the desire of the metric countries, which would, of course, prefer to use kilometres, to co-operate in this experiment. It seems probable that even in those countries which have not yet adopted these two units, the gradual pressure of world practice, the extent of which is indicated by the figure of 74 per cent, will lead to its adoption in countries which do not at present use these units.

An examination of the last five units shown in the table indicate that in their case the final position is much less certain. Generally speaking, the difficulty in adopting these units arises from the proposal to use metres in place of feet, and the continued vitality of the foot unit in opposition to a great deal of scientific opinion is quite remarkable. The outcome of the struggle between the foot and the metre will probably decide, for a considerable time, whether the world can agree on a single system of units for one of its most international services, that is, aviation, or whether there will have to be at least two major systems of units in general use.

\section{EARTHQUAKES DURING JANUARY-MARCH}

$\mathrm{D}$ URING the first quarter of 1950 there were four earthquakes of instrumental magnitude 7 or greater, sixteen of magnitude 6-7, and numerous smaller shocks. The four with magnitude 7 or greater occurred on January 2 in the Queen Charlotte Islands region $(M=7)$; on January 12 in the Fiji Islands region $(M=7)$; on February 28 off the north coast of Hokkaido, Japan $\left(M=7 \frac{3}{4}\right)$; and on March 27 off the south coast of Sumatra $(M=7)$. Fortunately all these had epicentres in uninhabited places, and only the Japanese shock was felt. Also during the three months three earthquakes had foci at depths of $500 \mathrm{~km}$. or deeper, seven had foci of $100-500 \mathrm{~km}$., and the rest had shallower foci. The three deep-focus earthquakes occurred on January 12, as mentioned above, in the Fiji Islands region $(d=500 \mathrm{~km}$.); on February 23 in the Sea of Okhotsk $(d=500 \mathrm{~km}$.); and on March 16 again in the Fiji Islands region $(a=600 \mathrm{~km}$.$) .$

Many minor shocks were felt during the three months. During January the following earthquakes and tremors were felt: on the 3rd of the month at Andinclaroby, Madagascar (Modified Mercalli Scale intensity 4); on the 4th in central Italy; and on the 6 th in Lisbon. On January 9 at $19 \mathrm{~h}$. $40 \mathrm{~m}$. 33s., G.M.T., an earthquake with epicentre near lat. $51 \cdot 1^{\circ}$ N., long. $1 \cdot 9^{\circ}$ E. was felt at several places along the Straits of Dover. People at Dover felt a severe tremor; and at St. Margaret's Bay, Kent, a slight tremor was felt and a noise like an explosion was heard, while at Deal doors and windows rattled and people felt chairs move. On the other side of the English Channel the tremor was felt at Calais where also plates were shaken from tables; but the tremor was not felt at Dunkirk or at Boulogne. On January 13 a tremor was felt at Mansourah-Les-Biban, Algeria (M.M. intensity 4); on the 16 th of the month one was felt at Bucharest (M.M. intensity 4); on the 2lst another in Central Chile; and on the 29th one was experienced at Walliser-Hochalpen (M.M. intensity 4). On January 31 an earthquake with epicentre at lat. $43^{\circ} \mathrm{N}$., long. $0^{\circ} 13^{\prime} \mathrm{E}$. near Campan in the Hautes 